\title{
Polycyclic Aromatic Hydrocarbons in PM 2.5 and PM10 From Industrial Area of Odisha, India: Sources, Atmospheric Transport and Health Risk Assessment
}

\section{Susmita Ekka}

central pollution control board

Sanjat Kumar Sahu

Sambalpur University

\section{Sanjeev Dwivedi}

IIT Bhubaneswar: Indian Institute of Technology Bhubaneswar

Sanjenbam Nirmala Khuman

SRM Institute of Science and Technology

\section{Shirsendu Das}

Scientific Research Laboratory, Santoshpur, Kolkata

Paromita Chakraborty ( $\sim$ paromita.c@res.srmuniv.ac.in )

SRM Research Institute https://orcid.org/0000-0002-4192-0992

\section{Research Article}

Keywords: PM2.5, PM10, PAHs, seasonal variation, source apportionment

Posted Date: February 9th, 2021

DOl: https://doi.org/10.21203/rs.3.rs-161643/v1

License: (c) (1) This work is licensed under a Creative Commons Attribution 4.0 International License.

Read Full License 


\section{Abstract}

In this study we aim to assess 16 priority PAHs enlisted by the US Environmental Protection Agency in PM 2.5 and PM 10 for the first time from industrial areas of Odisha State in India. During 2017-2018, bimonthly sampling of PM 10 and PM 2.5 were carried out for 24 hours by respirable dust sampler and PM 2.5 sampler respectively, in the industrial and mining areas of Jharsuguda $(n=2)$ and Angul $(n=4)$ during the pre-monsoon, monsoon and post monsoonal seasons. Highest average concentration of $\sum 16$ PAHs in PM 2.5 was observed during post monsoon $\left(170 \mathrm{ng} / \mathrm{m}^{3}\right)$ followed by pre-monsoon (17-89 $\mathrm{ng} / \mathrm{m}^{3}$; avg, $\left.48 \mathrm{ng} / \mathrm{m}^{3}\right)$ and monsoonal season $\left(2-40 \mathrm{ng} / \mathrm{m}^{3} ; \mathrm{avg}, 16 \mathrm{ng} / \mathrm{m}^{3}\right)$, respectively. Similar trend of $\sum 16$ PAHs levels in PM 10 was seen with higher levels during post monsoon $\left(116-471 \mathrm{ng} / \mathrm{m}^{3}\right.$; avg, $\left.286 \mathrm{ng} / \mathrm{m}^{3}\right)$ followed by pre-monsoon (avg, $81 \mathrm{ng} / \mathrm{m}^{3}$ ) and monsoon seasons $\left(27 \mathrm{ng} / \mathrm{m}^{3}\right.$. Diagnostic ratios $\mathrm{BaA} /(\mathrm{BaA}+\mathrm{Chry}), \mathrm{Phe} /(\mathrm{Phe}+\mathrm{Ant})$ and Flt/(Flt + Pyr) and principal component analysis (PCA) suggest diesel, gasoline and coal combustion are the major contributors for atmospheric PAHs pollution in Odisha. Back trajectories analysis revealed that PAHs concentration was affected majorly by air masses originating from the northwest direction traversing through central India. Toxic equivalents (TEQs) ranged between 0.24 to $94.13 \mathrm{ng} T E Q / \mathrm{m}^{3}$. In our study incremental lifetime cancer risk (ILCR) ranged between $10^{-5}$ and $10^{-3}$ representing potential cancer risk.

\section{Introduction}

Polycyclic aromatic hydrocarbons (PAHs) are of major concern due to their carcinogenicity, genotoxicity and ubiquitous nature. PAHs can be majorly formed during incomplete combustion (pyrolysis) or high temperature pyrolytic processes of organic materials and combustion of fossil fuels (Chen et al., 2007). They are pervasive environmental pollutants that are characterized by their hazardous carcinogenic and mutagenic potential (Carreras et al., 2013; McGrath et al., 2007). PAHs have received increased attention in recent years due to their diverse sources and their ubiquitous presence in all the environmental components (air, soil, and water) not only in developing but also in developed countries. The primary sources of PAHs are of anthropogenic origin viz., motor vehicle exhaust, petroleum refineries, heating in power plants, combustion of refuse, deposition from sewage, oil/gasoline spills, tobacco smoke, barbeque smoke and coke production (Christensen and Bzdusek, 2005; Moon et al., 2006). The US Environmental Protection Agency (USEPA) published a list of 16 priority PAHs in 1995. This list was expanded in 2008 to 28 priority compounds that present a serious hazard for human health (Ravindra et al., 2008). Benzo(a)pyrene (5-ring PAH) is the most commonly measured PAHs and is used as an indicator of carcinogenic hazard in polluted environments. Moreover PAHs with a larger number of aromatic rings are mostly bound to particulate matter associated with urban emissions (Possanzini et al., 2004). With the rapid social and economic development over the past several decades, air pollution due to PAHs has been both serious and widespread in India. The highest concentrations of atmospheric PAHs can be found in urban environments due to increasing vehicular traffic, coal combustion for power generation and low dispersion of the atmospheric pollutants (Caricchia et al., 1999). 
$\mathrm{PM}_{10}$ and $\mathrm{PM}_{2.5}$ are 25 to 100 times thinner than a human hair and can travel into the respiratory tract, penetrate deep into the lungs and even into the blood stream and cause severe health damage. Research shows that every $10 \mu \mathrm{g} / \mathrm{m}^{3}$ increase in $\mathrm{PM}_{2.5}$, increases all-cause mortality between 3-26\%, chances of childhood asthma by $16 \%$, chances of lung cancer by $36 \%$ and heart attacks by $44 \%$ (Airveda, 2017).

The state of Odisha has a tropical climate, characterized by high temperature and humidity, medium to high rainfall and mild winters. Serious air pollution in the industrial areas of Odisha over the past decade has attracted much attention. In India, studies were mainly carried out in large cities but no detailed study has been reported from Odisha despite the fact that the city is surrounded by multifarious industries of small, medium and large scales along with several coal mines. Hence, in the year 2017-2018 we took the

first attempt to monitor atmospheric PAHs in $\mathrm{PM}_{2.5}$ and $\mathrm{PM}_{10}$ in the industrial cities in the state of Odisha and the major objectives of this study were to (i) monitor 16 USEPA enlisted priority PAHs in two major industrial areas of Odisha viz., Angul and Jharsuguda during, summer or pre-monsoon (March - May), monsoon (June - September) and winter or post-monsoon (October - January) (ii) identify the probable sources by applying principal component analysis (PCA) and diagnostic ratios, (iii) identify the origin of air mass by Hybrid Single Particle Lagrangian Integrated Trajectory (HYSPLIT) Model's back-trajectory analysis (iv) assess the potential health risk posed by particulate-bound PAHs using USEPA health risk assessment model.

\section{Materials And Methods 2.1 Study Site}

Angul district is surrounded by Cuttack \& Dhenkanal on the east, Sambalpur \& Deogarh on the west, Sundargarh \& Keonjhar on the north and Phulbani on the south. Covering an area of $6232 \mathrm{sq.km}$, Angul District is located at Latitude $20.50^{\circ}$ north and $85.00^{\circ}$ east Longitude. Agriculture occupies a vital place in the economy of Angul district. However, in the last decade there is a tremendous growth in industrial sector. Jharsuguda is one of the most industrially developed districts of Odisha. The district is surrounded by Sundargarh district in the North, Sambalpur district in the East, Bargarh district in the South and Chattisgarh state in the West. Jharsuguda district is covering total area of 2,081 sq kms. The district is rich in minerals like coals, quartzite and fire clay. Besides deposits of limestone \& granite, white sand stone and laterite stone are also found in several places of Jharsuguda district that add to economy of the district. The district lies at $21.82^{\circ}$ north latitude and $84.1^{\circ}$ east longitude. Details of sampling locations are given in supporting information (SI) Table S1 alongwith the detailed site descriptions.

\subsection{Sample collection}

During all the seasons from March 2017 to January 2018 i.e., summer or pre-monsoon (March - May), monsoon (June - September) and winter or post - monsoon (October - January), twice in each season $\mathrm{PM}_{2.5}$ and $\mathrm{PM}_{10}$ sampling were conducted at Angul (from four substations) and Jharsuguda (from two substations), in the state of Odisha, India (Fig. 1). A total of $36 \mathrm{PM}_{2.5}$ samples and $108 \mathrm{PM}_{10}$ samples 
were collected during this sampling campaign. From Angul-Talcher, $24 \mathrm{PM}_{2.5}$ and $72 \mathrm{PM}_{10}$ samples were collected (for six times 3 samples were collected from each location of 4 sub-stations). From Jharsuguda, $12 \mathrm{PM}_{2.5}$ and $36 \mathrm{PM}_{10}$ samples (twice 3 samples were collected from each location of 2 substations) were collected. Details of sampling locations are given in Table S1 of supporting information (SI). The $\mathrm{PM}_{2.5}$ samples were collected using fine dust sampler (Envirotech APM - 550) which operated at a flow rate of $16.67 \mathrm{~L} / \mathrm{min}$ for $24 \mathrm{~h}$ to collect particle bound PAHs in PTFE Filter paper. $\mathrm{PM}_{10}$ sampler (Envirotech, APM $460 \mathrm{NL}$, India) was used with a flow of 0.9-1.1 L/min to collect particle bound PAHs in $20.3 \times 25.4 \mathrm{~cm}$ glass fiber filter (EPM 2000). Each sample for PM 10 was collected in three shifts (8 Hourly basis) in $24 \mathrm{~h}$ to avoid pressure drop due to loading of particulate matter on filter paper After 24 hours (h), the samples were taken and wrapped with aluminum foil and stored in desiccators. The sample filters were stabilized in a temperature and humidity-controlled incubator before and after collection at $25 \pm 1^{\circ} \mathrm{C}$ and $52 \pm 1 \%$ relative humidity for $24 \mathrm{~h}$.. All the filters were weighed using an electronic microbalance (Sartorius T-114) before analysis. Filter papers wrapped in aluminium foils and stored at $-20^{\circ} \mathrm{C}$ prior to analysis. Filter papers were desiccated for $24 \mathrm{~h}$ before taking initial weight prior to the sampling. In the same manner final weight for filter papers were taken after sample collection.

\subsection{Sample extraction and clean up}

Exposed filter paper was cut into small pieces in a $250 \mathrm{~mL}$ beaker. Ultrasonic extraction was conducted using $100 \mathrm{~mL}$ of toluene and was repeated for three times. The extracted samples were then filtered using Whatman filter paper and were pooled together. The pooled extracts were reduced to $\sim 1 \mathrm{~mL}$ using rotary evaporator with water bath (temp below $40^{\circ} \mathrm{C}$ ).

Clean-up was performed using silica gel column having length of $200 \mathrm{~mm}$ and inner diameter (ID) of 0.5 $\mathrm{cm}$. Slurry of $3 \mathrm{~g}$ deactivated silica gel (60-100 mesh size) in cyclohexane was poured into the column. Conditioning was performed using toluene followed by cyclohexane. Samples were passed drop-wise and eluted using cyclohexane. Further, $30 \mathrm{~mL}$ of cyclohexane were added to the column to elute all organics of interest. Pooled samples were reduced to $1 \mathrm{~mL}$ and store in a dark and cool place.

\subsection{Instrumental analysis}

Sixteen priority PAHs were analysed using Agilent 7820A gas chromatograph coupled with Agilent 19091, $\mathrm{J}-413,325{ }^{\circ} \mathrm{C}$ capillary column $(30 \mathrm{~m} \times 0.32 \mathrm{~mm} \times 0.25 \mu \mathrm{m}) .2 \mu \mathrm{L}$ of each sample was injected in splitless mode. High purity $99.999 \%$ nitrogen was used as the carrier gas, with a flow rate of $1 \mathrm{~mL} / \mathrm{min}$. The temperature of the injector and transfer lines were $250{ }^{\circ} \mathrm{C}$ and $300{ }^{\circ} \mathrm{C}$ respectively. The initial oven temperature was set at $120{ }^{\circ} \mathrm{C}$ for $2 \mathrm{~min}$, increased to $300{ }^{\circ} \mathrm{C}$ at a rate of $7{ }^{\circ} \mathrm{C} / \mathrm{min}$ and then maintained for $10 \mathrm{~min}$. The concentrations of $16 \mathrm{PAHs}$ were quantified according to their elution orders as follows; naphthalene (Nap, m/z 128), acenaphthylene (Acy, m/z 152), acenaphthene (Ace, m/z 154), fluorene (Flu, $\mathrm{m} / \mathrm{z}$ 166), phenanthrene (Phe, $\mathrm{m} / \mathrm{z}$ 178), anthracene (Ant, $\mathrm{m} / \mathrm{z}$ 178), fluoranthene (Flt, $\mathrm{m} / \mathrm{z}$ 202), pyrene (Pyr, $\mathrm{m} / \mathrm{z}$ 202), benzo(a)anthracene (BaA, $\mathrm{m} / \mathrm{z} 228$ ), chrysene (Chry, $\mathrm{m} / \mathrm{z} 228)$, benzo (b) fluoranthene (BbF, $\mathrm{m} / \mathrm{z} 252)$, benzo(k)fluoranthene (BkF, $\mathrm{m} / \mathrm{z} 252)$, benzo(a)pyrene (BaP, $\mathrm{m} / \mathrm{z} 252)$, indeno(1,2,3cd)pyrene (InP, m/z 276), dibenzo(a,h)anthracene (DBA, m/z 278), benzo(ghi)perylene (BghP, m/z 276). 


\subsection{Quality assurance and control}

The analytical method was based on the USEPA Method T0-13. Field blanks, filter blanks and solvent blanks were analyzed by the same procedure as the samples and it was ensured that there were no significant background interferences. The quantifications were performed using the internal standard method. For quality control check SRM urban dust No 1649a was used to check recovery. Recovery \% was between $75-130 \%$ and is presented in details in SI Table S2.

\subsection{Atmospheric Transport Model}

HYbrid Single-Particle Lagrangian Integrated Trajectory (HYSPLIT) is an atmospheric model developed by National Oceanic and Atmospheric Administration (NOAA) Air Resource Laboratory, which has proven as a powerful tool for researchers to simulate the transport of particles in the atmosphere and provide information on where air-parcels originate from (Draxler et al., 1999; Hegarty et al., 2013; Maurer et al., 2018). HYSPLIT has the ability for a hybrid calculation approach and uses both Lagrangian (moving frame of reference for diffusion and advection) and Eulerian (fixed model grid for calculation of air concentration) methods (Stein et al., 2015)

\subsection{Statistical analysis}

All statistical analyses were performed using IBM-SPSS Statistics software (version 22). All the tests of significance were performed using analysis of variance (ANOVA) and t-test.

\subsection{Risk assessment}

\subsubsection{Toxic equivalents}

Toxic equivalents (TEQs) of the PAHs were calculated using toxicity equivalent factors (TEF) of all PAHs. The following equation was used to calculate the toxicity as done in earlier studies (Chen and Chen, 2011; Li et al., 2015; Nasher et al., 2013; Peters et al., 1999)

Total TEQ $=\sum \mathrm{C}_{\mathrm{i}} \times \mathrm{TEF}_{\mathrm{i}}$

where, $C_{i}=$ concentration of individual PAH fraction, $\mathrm{TEF}_{\mathrm{i}}=$ toxicity factor relative, which represents the ratio of the toxicity of a PAH congener to that of $\mathrm{B}(\mathrm{a}) \mathrm{P}$.

The TEF of all the individual PAHs are given in SI Table S3 (Cincinelli et al., 2007; EPA, 1993).

\subsubsection{Cancer Risk Assessment}

Incremental lifetime cancer risk (ILCR) exposure to carcinogenic PAHs (BaA, Chry, BkF, BbF, BaP, Ind, and $\mathrm{DbA}$ ) were estimated by using the lifetime average daily dose (LADD) and the cancer slope factor (CSF). 
The LADD is the intake quantity of a known pollutant with a potential to cause adverse health effects when absorbed into the body over a period of time (Jamhari et al., 2014). In this study, the LADD and the ILCR were computed for infants ( 0 - 1 year), children ( $2-5$ years), children (6-12 years), and adults (1975 years). The $L A D D s$ through the inhalation $\left(L A D D_{\text {inh }}\right)$, ingestion $\left(L A D D_{\text {ing }}\right)$, and dermal $\left(L A D D_{\text {derm }}\right)$ pathways were estimated using

$\mathrm{LADD}_{\text {inh }}=[\mathrm{C} \times \operatorname{lnhR} \times \mathrm{ET} \times \mathrm{EF} \times \mathrm{ED} \times \mathrm{CF}] /[\mathrm{BW} \times \mathrm{AT}]$

$\mathrm{LADD}_{\text {ing }}=[\mathrm{C} \times \operatorname{IngR} \times \mathrm{ET} \times \mathrm{EF} \times \mathrm{ED} \times \mathrm{CF}] /[\mathrm{BW} \times \mathrm{AT}]$

$\mathrm{LADD}_{\text {derm }}=[\mathrm{C} \times \mathrm{SA} \times \mathrm{AF} \times \mathrm{ABS} \times \mathrm{ET} \times \mathrm{EF} \times \mathrm{ED} \times \mathrm{CF}] /[\mathrm{BW} \times \mathrm{AT}]$

$\mathrm{ILCR}=\mathrm{LADD} \times \mathrm{CSF}$

where $\mathrm{C}=$ concentration of PAHs $\left(\mathrm{ng} / \mathrm{m}^{3}\right)$; $\mathrm{ED}=$ exposure duration (days); $\mathrm{BW}=$ body weight of the exposed group (kg); AT = averaging time (days), ET = exposure time (h/day); IngR = ingestion rate $\left(\mathrm{mg} /\right.$ day); InhR = inhalation rate $\left(\mathrm{m}^{3} /\right.$ day); $\mathrm{SA}=$ surface area of the skin exposed to pollutants $\left(\mathrm{cm}^{2}\right) ; \mathrm{AF}=$ skin adherence factor $\left(\mathrm{mg} / \mathrm{cm}^{2} /\right.$ day); $A B S=$ dermal absorption factor; $E F=$ exposure frequency (days/year); $\mathrm{CSF}=$ cancer slope factor $\left(\mathrm{mg}^{-1} \mathrm{~kg}\right.$ day) and $\mathrm{CF}=$ unit conversion factor $\left(\mathrm{C}=10^{-6}\right)$. The values of these parameters are taken from a previous study (Morakinyo et al., 2019b).

\section{Results And Discussion}

\subsection{Levels and comparison with other studies}

\section{$\mathrm{PM}_{2.5}$}

The overall range of $\sum_{16} \mathrm{PAHs}$ in $\mathrm{PM}_{2.5}$ during pre-monsoon, monsoon and post-monsoon were 17-89 $\mathrm{ng} / \mathrm{m}^{3}, 2-40 \mathrm{ng} / \mathrm{m}^{3}$ and $74-282 \mathrm{ng} / \mathrm{m}^{3}$ respectively. The mean concentration of total carcinogenic PAHs in Jharsuguda and Angul was $52 \mathrm{ng} / \mathrm{m}^{3}$ and $40 \mathrm{ng} / \mathrm{m}^{3}$ respectively. The mean concentration of $\sum_{16} \mathrm{PAHs}$ in Jharsuguda $\left(102 \mathrm{ng} / \mathrm{m}^{3}\right)$ was two folds higher than Angul $\left(66 \mathrm{ng} / \mathrm{m}^{3}\right)$ (Table 1). In both sites, the overall trend of PAHs pollution was observed as post monsoon $>$ pre monsoon $>$ monsoon ( $\mathrm{SI}$ Table S4 and S5). Concentration of $\sum_{16} \mathrm{PAHs}$ in Odisha during post monsoon was 3 folds higher than pre monsoon and 10 folds higher than monsoon. $\mathrm{PM}_{2.5}$ bound PAHs were significantly different $(p<0.05)$ between three seasons (SI Table S8). Furthermore, significant difference of individual PAHs between different seasons were observed in all the stations $(p<0.05)$. The overall mean concentration for all the seasons for $\sum_{16} \mathrm{PAHs}$ in $\mathrm{PM}_{2.5}$ in industrial regions of Odisha was slightly lower than Zhengzhou (111 $\mathrm{ng} / \mathrm{m}^{3}$ ) (Wang et al., 2014). Mean $\sum_{16} \mathrm{PAHs}$ concentrations in industrial sites of Odisha were comparable with Beijing (244 ng/m³) (Wang et al., 2008), Nanjing (125 ng/m³) (Wang et al., 2007), Xian (140 ng/m³) (Bandowe et al., 2014) in China, New Delhi in India (105 ng/m³), (Sarkar and Khillare, 2013), Zonguldak in 
Turkey $\left(94 \mathrm{ng} / \mathrm{m}^{3}\right)$ (Akyüz and Çabuk, 2009) but higher than Atlanta in USA (3 ng/ $\left.\mathrm{m}^{3}\right)$ (Li et al.2009), Norway $\left(8.60 \mathrm{ng} / \mathrm{m}^{3}\right)$ and United Kingdom $\left(11.20 \mathrm{ng} / \mathrm{m}^{3}\right.$ ) (Eeftens et al., 2012) and Madrid in Spain (15 $\mathrm{ng} / \mathrm{m}^{3}$ ) (Barrado et al., 2013) (Table S6). 
Table 1

Concentration of PAHs in the two industrial region in Orissa, India

\begin{tabular}{|c|c|c|c|c|c|c|c|c|}
\hline \multirow{3}{*}{$\begin{array}{l}\text { Concentration } \\
\text { in } \\
\mathrm{ng} \mathrm{m}^{-3}\end{array}$} & \multicolumn{4}{|c|}{ JHARSUGUDA } & \multicolumn{4}{|l|}{ ANGUL } \\
\hline & \multicolumn{2}{|l|}{ PM 2.5} & \multicolumn{2}{|l|}{ PM 10} & \multicolumn{2}{|l|}{ PM 2.5} & \multicolumn{2}{|l|}{ PM 10} \\
\hline & RANGE & $\begin{array}{l}\text { AVG } \\
\pm \text { SD }\end{array}$ & RANGE & $\begin{array}{l}\text { AVG } \\
\pm \text { SD }\end{array}$ & RANGE & $\begin{array}{l}\text { AVG } \\
\pm \text { SD }\end{array}$ & RANGE & $\begin{array}{l}\text { AVG } \\
\pm \text { SD }\end{array}$ \\
\hline Naphthalene & $\begin{array}{l}\text { nd - } \\
92\end{array}$ & $\begin{array}{l}24 \pm \\
33\end{array}$ & $\begin{array}{l}\text { nd - } \\
153\end{array}$ & $\begin{array}{l}40 \pm \\
54\end{array}$ & nd -41 & $6 \pm 9$ & nd -68 & $\begin{array}{l}10 \pm \\
14\end{array}$ \\
\hline 2 Rings & $\begin{array}{l}\text { nd - } \\
92\end{array}$ & $\begin{array}{l}24 \pm \\
33\end{array}$ & $\begin{array}{l}\text { nd - } \\
153\end{array}$ & $\begin{array}{l}40 \pm \\
54\end{array}$ & nd -41 & $6 \pm 9$ & nd -68 & $\begin{array}{l}10 \pm \\
14\end{array}$ \\
\hline Acenaphthylene & $\begin{array}{l}\text { nd - } \\
20\end{array}$ & $6 \pm 7$ & $\begin{array}{l}\text { nd - } \\
35\end{array}$ & $\begin{array}{l}9 \pm \\
13\end{array}$ & nd -20 & $3 \pm 6$ & nd -33 & $\begin{array}{l}6 \pm \\
9\end{array}$ \\
\hline Acenaphthene & $\begin{array}{l}\text { nd - } \\
18\end{array}$ & $4 \pm 5$ & $\begin{array}{l}\text { nd - } \\
32\end{array}$ & $7 \pm 9$ & nd -10 & $1 \pm 2$ & nd -17 & $\begin{array}{l}2 \pm \\
4\end{array}$ \\
\hline Fluorene & $\mathrm{nd}-7$ & $3 \pm 2$ & $1-11$ & $5 \pm 4$ & nd -64 & $\begin{array}{l}6 \pm \\
14\end{array}$ & $\begin{array}{l}\text { nd } \\
-104\end{array}$ & $\begin{array}{l}11 \pm \\
23\end{array}$ \\
\hline Phenanthrene & $\mathrm{nd}-8$ & $3 \pm 3$ & $1-14$ & $4 \pm 5$ & nd -27 & $3 \pm 6$ & nd -43 & $\begin{array}{l}4 \pm \\
10\end{array}$ \\
\hline Anthracene & $\mathrm{nd}-2$ & $1 \pm 1$ & $\mathrm{nd}-4$ & $1 \pm 1$ & nd -4 & $1 \pm 1$ & nd -6 & $\begin{array}{l}2 \pm \\
2\end{array}$ \\
\hline 3 Rings & $1-49$ & $\begin{array}{l}16 \pm \\
16\end{array}$ & $2-86$ & $\begin{array}{l}27 \pm \\
28\end{array}$ & nd -98 & $\begin{array}{l}14 \pm \\
24\end{array}$ & $\begin{array}{l}\text { nd } \\
-158\end{array}$ & $\begin{array}{l}24 \pm \\
40\end{array}$ \\
\hline Fluoranthene & $\mathrm{nd}-7$ & $3 \pm 3$ & $\begin{array}{l}\text { nd - } \\
13\end{array}$ & $6 \pm 5$ & nd -20 & $2 \pm 4$ & nd -33 & $\begin{array}{l}4 \pm \\
7\end{array}$ \\
\hline Pyrene & $\mathrm{nd}-3$ & $1 \pm 1$ & nd -5 & $2 \pm 2$ & nd -4 & $1 \pm 1$ & nd -8 & $\begin{array}{l}1 \pm \\
2\end{array}$ \\
\hline Benzo(a)anthracene & $\begin{array}{l}\text { nd - } \\
24\end{array}$ & $6 \pm 9$ & $\begin{array}{l}\text { nd - } \\
41\end{array}$ & $\begin{array}{l}11 \pm \\
15\end{array}$ & nd -13 & $3 \pm 3$ & nd -21 & $\begin{array}{l}4 \pm \\
5\end{array}$ \\
\hline Chrysene & $\begin{array}{l}\text { nd - } \\
69\end{array}$ & $\begin{array}{l}17 \pm \\
23\end{array}$ & $\begin{array}{l}\text { nd - } \\
114\end{array}$ & $\begin{array}{l}29 \pm \\
36\end{array}$ & nd -36 & $\begin{array}{l}9 \pm \\
10\end{array}$ & nd -59 & $\begin{array}{l}15 \pm \\
16\end{array}$ \\
\hline 4 Rings & $\begin{array}{l}\text { nd - } \\
100\end{array}$ & $\begin{array}{l}27 \pm \\
31\end{array}$ & $\begin{array}{l}\text { nd - } \\
170\end{array}$ & $\begin{array}{l}47 \pm \\
53\end{array}$ & nd -53 & $\begin{array}{l}15 \pm \\
16\end{array}$ & nd -88 & $\begin{array}{l}25 \pm \\
26\end{array}$ \\
\hline Benzo(b)fluoranthene & $\begin{array}{l}\text { nd - } \\
15\end{array}$ & $5 \pm 5$ & $\begin{array}{l}\text { nd - } \\
53\end{array}$ & $\begin{array}{l}10 \pm \\
15\end{array}$ & nd -40 & $\begin{array}{l}13 \pm \\
11\end{array}$ & nd -66 & $\begin{array}{l}21 \pm \\
18\end{array}$ \\
\hline Benzo(k)fluoranthene & $\begin{array}{l}\text { nd - } \\
19\end{array}$ & $4 \pm 7$ & $\begin{array}{l}\text { nd - } \\
32\end{array}$ & $\begin{array}{l}7 \pm \\
12\end{array}$ & nd & - & nd & - \\
\hline Benzo(a)pyrene & $1-38$ & $\begin{array}{l}15 \pm \\
10\end{array}$ & $2-63$ & $\begin{array}{l}27 \pm \\
17\end{array}$ & nd -35 & $\begin{array}{l}13 \pm \\
11\end{array}$ & nd -59 & $\begin{array}{l}22 \pm \\
18\end{array}$ \\
\hline
\end{tabular}




\begin{tabular}{|c|c|c|c|c|c|c|c|c|}
\hline \multirow{3}{*}{$\begin{array}{l}\text { Concentration } \\
\text { in } \\
\mathrm{ng} \mathrm{m}^{-3}\end{array}$} & \multicolumn{4}{|c|}{ JHARSUGUDA } & \multicolumn{4}{|l|}{ ANGUL } \\
\hline & \multicolumn{2}{|l|}{ PM 2.5} & \multicolumn{2}{|l|}{ PM 10} & \multicolumn{2}{|l|}{ PM 2.5} & \multicolumn{2}{|l|}{ PM 10} \\
\hline & RANGE & $\begin{array}{l}\text { AVG } \\
\pm S D\end{array}$ & RANGE & $\begin{array}{l}\text { AVG } \\
\pm S D\end{array}$ & RANGE & $\begin{array}{l}\text { AVG } \\
\pm S D\end{array}$ & RANGE & $\begin{array}{l}\text { AVG } \\
\pm \text { SD }\end{array}$ \\
\hline 5 Rings & $1-57$ & $\begin{array}{l}24 \pm \\
18\end{array}$ & $3-129$ & $\begin{array}{l}44 \pm \\
36\end{array}$ & nd -64 & $\begin{array}{l}26 \pm \\
21\end{array}$ & $\begin{array}{l}\text { nd } \\
-106\end{array}$ & $\begin{array}{l}43 \pm \\
35\end{array}$ \\
\hline Indeno(1,2,3-cd)pyrene & $\mathrm{nd}-7$ & $2 \pm 2$ & $\begin{array}{l}\text { nd - } \\
12\end{array}$ & $3 \pm 4$ & nd -13 & $2 \pm 3$ & nd -21 & $\begin{array}{l}3 \pm \\
4\end{array}$ \\
\hline Dibenzo(a,h)anthracene & $\begin{array}{l}\text { nd - } \\
12\end{array}$ & $2 \pm 4$ & $\begin{array}{l}\text { nd - } \\
19\end{array}$ & $4 \pm 6$ & nd -2 & $0 \pm 1$ & nd -3 & $\begin{array}{l}1 \pm \\
1\end{array}$ \\
\hline Benzo(ghi) Perylene & $\begin{array}{l}\text { nd - } \\
23\end{array}$ & $7 \pm 8$ & $\begin{array}{l}\text { nd - } \\
39\end{array}$ & $\begin{array}{l}12 \pm \\
14\end{array}$ & nd -6 & $2 \pm 2$ & nd -11 & $\begin{array}{l}4 \pm \\
3\end{array}$ \\
\hline 6 Rings & $\begin{array}{l}\text { nd - } \\
36\end{array}$ & $\begin{array}{l}11 \pm \\
13\end{array}$ & $\begin{array}{l}\text { nd - } \\
62\end{array}$ & $\begin{array}{l}19 \pm \\
22\end{array}$ & nd -16 & $4 \pm 4$ & $1-26$ & $\begin{array}{l}7 \pm \\
6\end{array}$ \\
\hline$\sum_{16} \mathrm{PAHs}$ & $2-282$ & $\begin{array}{l}102 \\
\pm 101\end{array}$ & $6-479$ & $\begin{array}{l}176 \\
\pm 172\end{array}$ & $2-234$ & $\begin{array}{l}66 \pm \\
66\end{array}$ & $3-387$ & $\begin{array}{l}109 \\
\pm \\
108\end{array}$ \\
\hline Carcenogenic PAHs & $1-133$ & $\begin{array}{l}52 \pm \\
44\end{array}$ & $3-229$ & $\begin{array}{l}90 \pm \\
77\end{array}$ & $1-108$ & $\begin{array}{l}40 \pm \\
34\end{array}$ & $1-180$ & $\begin{array}{l}66 \pm \\
55\end{array}$ \\
\hline
\end{tabular}

$\mathrm{PM}_{10}$

Overall range of $\sum_{16} \mathrm{PAHs}$ in $\mathrm{PM}_{10}$ during pre-monsoon, monsoon and post-monsoon were 34-145 $\mathrm{ng} / \mathrm{m}^{3}, 3-65 \mathrm{ng} / \mathrm{m}^{3}$ and $116-479 \mathrm{ng} / \mathrm{m}^{3}$, respectively. Similar to the trend of $\mathrm{PM}_{2.5}$, the mean concentrations of total and carcinogenic PAHs were highest during post monsoon season. The mean concentration of $\sum_{16}$ PAHs for all the seasons in Jharsuguda $\left(176 \mathrm{ng} / \mathrm{m}^{3}\right)$ was higher than Angul site $\left(109 \mathrm{ng} / \mathrm{m}^{3}\right)$ (Table S4 and S5). PAHs pollution was observed in the order post monsoon > pre monsoon > monsoon which is in line with the observation in $\mathrm{PM}_{2.5}$. $\mathrm{PM}_{10}$ bound PAHs were significantly different ( $p$ $<0.05$ ) between three seasons (SI Table S9). Furthermore, significant difference of individual PAHs between different seasons were observed in all the stations $(p<0.05)$. Higher PAHs level in the postmonsoonal season can be reasoned with lower temperature, photochemical composition and radiation thereby reducing the evaporation from particulate to the vapour phase and stronger photochemical composition of PAHs (Feng et al., 2005; Odabasi et al., 1999). However, lower concentrations of PAHs during monsoon can be associated with washing out effect for particulates (Karar and Gupta, 2006).

The mean concentration of total PAHs in PM $10\left(131 \mathrm{ng} / \mathrm{m}^{3}\right)$ was higher than Agra $\left(43 \mathrm{ng} / \mathrm{m}^{3}\right)$ (Masih et al., 2010), Visakhapatnam (57 ng/m³ ) (Kulkarni et al., 2014) but lower than Kanpur (616 ng/m ${ }^{3}$ ) (Singh et al., 2015), Tiruchirapalli (259 ng/m³) (Mohanraj et al., 2011) and Amritsar (154 ng/m³) (Kaur et al., 2013) 
in India. The mean concentration of total PAHs were higher than urban Malaysia $\left(6 \mathrm{ng} / \mathrm{m}^{3}\right)(\mathrm{Omar}$ et al., 2002) and Xiamen in China (15 ng/ $\mathrm{m}^{3}$ ) (Hong et al., 2007) (Table S7).

\subsection{Seasonality and back trajectory analysis}

HYSPLIT back trajectories analysis were performed over both Angul and Jharsuguda (Fig. 2). The air mass five days back trajectories for each hour (00 to $23 \mathrm{Z}$ ) at height of $500 \mathrm{~m}$ above ground level (AGL) of 144 trajectories ( 6 Days $\times 24$ hours $=144$ trajectories) were clustered into 3 clusters. Each site had different 6 day samples and the Reanalysis data resolution was $2.5^{\circ} \times 2.5^{\circ}$, for Angul, single plot was made for 4 locations. Radiosonde data over Bhubaneswar from University of Wyoming (Department of Atmospheric Science, University of Wyoming, http://weather.uwyo.edu/upperair/sounding.html) was used for the 6 days corresponding to sample collection dates.

Figure 2 a shows the three major clusters at Angul site. The three cluster types were studied as per direction, location traced and seasons. About $50 \%$ of the trajectories $(n=72)$ were during the $22 n d$ March 2017 and winter time (23rd November 2017 and 15th January 2018) originating from the North-West location from a landmass which was a major dust source. Cluster 1 was traversing through the industrial locations of Rajasthan, Uttar Pradesh and Chhattisgarh for 4 days and settling down at $500 \mathrm{~m}$ height from $2000 \mathrm{~m}$. Air masses in Cluster 1 constituted more than $85 \%$ of total and carcinogenic PAHs in both $\mathrm{PM}_{2.5}$ and $\mathrm{PM}_{10}$. Cluster 2 (mainly during monsoon season) which was $33 \%$ of total trajectories traversed through the south Indian states, Karnataka and Telangana and were below $500 \mathrm{~m}$ Above Ground Level (AGL) and finally crossed throughout Odisha in the last 2 days before reaching Angul. This cluster had more impact from south-west monsoon seasonal winds. Cluster 3 (17\%) arrived from the Bay of Bengal via Indian Ocean during the pre- monsoon on dated 24th May and originated from Indian Ocean and Arabian Sea. Interestingly, Cluster 2 and 3 together constituted less than $10 \%$ of the total PAHs and carcinogenic PAHs in both $\mathrm{PM}_{2.5}$ and $\mathrm{PM}_{10}$. Thus, this cluster was affected mostly by localized emission sources from 12 hours journey over Odisha. This hypothesis has been further supported by wind rose showing the exact wind direction (Fig. 2b). Between 4 to $9 \%$ frequency of highspeed wind were coming between North-West and North. Winds with a speed of 10-15 m/s were coming from the South and South-West directions. Figure 2c shows Cluster 1, which contributed about one third of total back trajectories that came from Arabian Sea via Maharashtra and Chhattisgarh during the winter season and traversed from west and from a height below 500 m AGL.

Over Jharsuguda, wind rose showed $10 \mathrm{~m} / \mathrm{s}$ to $>15 \mathrm{~m} / \mathrm{s}$ winds (with 1.6-6.4 \% frequency) from the west (Fig. 2d). Over Jharsuguda, most of the trajectories (Cluster 2) arose from the industrial regions of IndoGangetic plain and we suspect the possibility of long range atmospheric transport from such emission regions. Thus, this cluster can be associated with a mixer of long-range transport and local pollution sources mainly from vehicular and industrial sources. Cluster 2 (50 \%) was traversing during specific dates (21st March, 21st November, 21st December) during winter and pre-monsoon seasons of 2017 originating from north and North-West along the Indo - Gangetic plain (Fig. 2e). These months constituted nearly 80 to 85 \% of total PAHs and carcinogenic PAHs in $\mathrm{PM}_{2.5}$ and $\mathrm{PM}_{10}$. It originated from the Arabian 
Sea and crossed over the states, Maharashtra and Chhattisgarh for 3 days before ending in this sampling site. Wind rose indicates high wind speed coming from North and North-West directions (Fig. 2b). In 2017, on 26th May, the 3rd cluster (17 \%) originating from south and south-west i.e. the Bay of Bengal and can be used to track local sources pollution especially from vehicles and local industries. The maximum transfer of PAHs air parcel was observed during the winter season (November, December) followed by pre-monsoon (March) over both Angul and Jharsuguda sites. This winter season atmospheric transport might be caused by western disturbance, which brings the pollutant from industrial areas of IndoGangetic plains to the study area.

\subsection{Source apportionment}

PAHs can be classified by the number of aromatic rings such as two rings (Nap), three rings (Acy, Ace, Flu, Phe, Ant), four rings (Flt, Pyr, BaA, Chry), five rings (BbF, BkF, BaP, DBA) and six rings (InP, BghiP) and this was used to construct the distribution pattern of the PAHs. Some studies have reported that the low molecular weight PAHs (LMW, 2-3 ring) mainly exist in the coarse part of the PM (Tan et al., 2011). In this study, both the high molecular weight PAHs (HMW, 4-6 rings) and LMW PAHs mainly existed in the fine particles. During all the seasons 5 ring PAHs was dominant in all the locations (Table S10 \& S11). $\mathrm{LMW} / \mathrm{HMW}$ ratios of PAHs were in the range of $0.13-0.33,0.02-0.76$, and $0.24-0.9$ during summer, monsoon and post monsoonal seasons respectively. Box-whisker plots representing ring wise distribution of PAHs in $\mathrm{PM}_{2.5}$ and $\mathrm{PM}_{10}$ among the three seasons in the two major industrial regions of Odisha are shown in Fig. 3.

PAHs viz. Flu, Pyr ,Chry, BbF, BkF, BaA, BaP, InP and BghiP were classified as combustion derived PAHs (сомPAHs). The $\sum_{\text {com }}$ PAHs contributed between 54 to $97 \%$ of the $\sum_{16} \mathrm{PAHs}$ in $\mathrm{PM}_{10}$ and 14 to $100 \%$ in $\mathrm{PM}_{2.5}$ respectively. There was a clear difference in post-monsoonal samples from the other seasons and some deviations in each sampling site. In monsoon and post- monsoon season, combustion derived PAHs constituted more than half of the $\sum_{16} \mathrm{PAHs}$. Ratio of ${ }_{\mathrm{COM}} \mathrm{PAH} / \sum_{16} \mathrm{PAH}$ ratios were determined for non-catalyst (0.4) and catalyst equipped (0.5) automobiles and for heavy-duty diesel trucks (0.3) (Rogge et al., 1993). In this study the values of ${ }_{\mathrm{COM}} \mathrm{PAH} / \sum_{16} \mathrm{PAH}$ varied between $0.74-0.85,0.53-0.97$ and 0.52-0.79 during pre-monsoon, monsoon post-monsoonal seasons. Ratio of 0.5 might be from catalyst equipped automobiles mainly observed in winter season, however, the ratios in other seasons varying between 0.74 to 0.97 might indicate a complex source. Seven carcinogenic PAHs ( $\left.\sum_{7 \text { carc }} \mathrm{PAHs}\right)$ are another important category for monitoring pollutants in the atmosphere to assess the carcinogenic potential of PAHs to humans. Mean concentration of $\sum_{7 \text { carc }}$ PAHs followed the trend as: post-monsoon > pre-monsoon > monsoon in both $\mathrm{PM}_{2.5}$ and $\mathrm{PM}_{10}$ across industrial regions of Jharsuguda (Table S4) and Angul (Table S5).

PAHs have been used as tracers to distinguish between diverse sources (Lodovici et al., 2003; Vasconcellos et al., 2003). For the source apportionment, various diagnostic ratios were combined with principal component analysis to arrive at a suitable source type for a specific group of PAHs. Diagnostic ratios of PAHs are usually an effective way to identify sources because they exhibit the characteristics of 
specific sources, but they should be used carefully because some of them are variable in different ambient conditions due to the reactivity of some PAH species, such as the photolytic decomposition of $\mathrm{BaP}$ (Feng et al., 2005; Odabasi et al., 1999). Diagnostic ratio of Flt/(Flt + pyr) (Yunker et al., 2002), BbF/BkF(Agarwal et al., 2009), BaA/(BaA + Chry)(Ping et al., 2007), BaA/Chry (Wang et al., 2010), $\mathrm{BaP} / \mathrm{BgP}$ (Wang et al., 2007) and $\sum_{7 \mathrm{carc}} \mathrm{PAHs} / \sum_{16} \mathrm{PAHs}$ (Zhang et al., 2006) were used in this study to understand the specific source type.

PC-1: First component represented $52 \%$ of the total variance and was strongly weighted with LMW-PAHs, such as Nap, Ace and Acy and HMW-PAHs viz. BaA, Chry, BkF, DBA and BgP with best fit >0.7. Ace, Chry, $\mathrm{BgP}(\mathrm{SI}$ Table 16) are reported to be sourced mainly from traffic exhausts emission in India (Cheng et al., 2013). $\mathrm{BaA} /(\mathrm{BaA}+\mathrm{Chry})$ ratio has been used to evaluate the contribution of vehicular emissions. Across all the seasons in both the sites, the mean ratio was observed less than 0.3 indicating catalyst equipped vehicles (Gogou et al., 1996) as the main vehicular emission source. Nap and Acy might have resulted from the coal combustion emission. Likewise, $\mathrm{BaP}$ and Ace might have resulted from coal and gasoline emission. This component can therefore represent PAHs sources mainly from vehicular emission.

PC-2: With $17 \%$ variance, this component was mainly loaded with Flu, Ant, Phe, BbF and BaP. HMW PAHs like four to five rings can be significantly emitted from light vehicles and Fluoranthene is an indicator for heavy-duty diesel combustion (Marr et al., 1999). Pyr, BaA, Chry and Fl are markers for coal combustion (Tavakoly Sany et al., 2014) and BaP for biomass burning (Belis et al., 2011). Flu, Phe, Flt, and Ant could be from diesel-powered vehicle emissions. Phe/(Phe + Ant) ratio has been used to identify the importance of petrogenic hydrocarbons in relation to emission from biomass burning. Mean value of Phe/(Phe + Ant) ratio in both $\mathrm{PM}_{2.5}$ and $\mathrm{PM}_{10}$ in Jharsuguda and Angul across all the seasons were greater than 0.1 indicating petrogenic sources (Table S12 and S13). Mean Flt/(Flt + Pyr) ratio in all the sites across all the seasons were greater than 0.5 indicating diesel combustion as a major source type. This component can therefore represent mixed source types due to biomass combustion and petrogenic emission.

PC-3: With $7 \%$ variance, this component was weighted only with $\operatorname{InP}$. Mean value for the ratio of $\mathrm{InP} /(\mathrm{InP}$ $+\mathrm{BgP}$ ) was 0.5 in both $\mathrm{PM}_{2.5}$ and $\mathrm{PM}_{10}$ in Angul during all the seasons. However in Jharsuguda the values for this ratio during pre -monsoon was $>0.7$ in both $\mathrm{PM}_{2.5}$ and $\mathrm{PM}_{10}$ but in other seasons the ratio was < 0.3.The ratio between 0.37-0.70 indicate diesel emissions (Kavouras et al., 1999),(Alves et al., 2017; Pio et al., 2001) and >0.5 indicates coal, wood combustion (Gogou et al., 1996; Pio et al., 2001).

\subsection{Intra-site variation}

At different sampling sites in Angul, In $\mathrm{PM}_{10}, \sum_{16} \mathrm{PAHs}$ during pre-monsoon followed the trend: $\mathrm{A}$ 1(Nalco Township) $>$ A3 (TTPS) $>A 4(M C L)>A 2$ (Hakimpada). During monsoon the trend was as: $A 1>A 2>A 3>A 4$ and during post-monsoon it was A1 $>A 4>A 3>A 2$ in Angul. Similar trend was observed for $\sum_{16}$ PAHs in $\mathrm{PM}_{2.5}$ across all the seasons. This results strongly suggested that site $\mathrm{A} 1$ was the most polluted area and this may be due to the impact of vehicular emission of highway and the township near Nalco Smelter and its captive power plant and proximity to Talcher Thermal power plant and coal mine area. It is to be 
noted that this location is impacted by heavy vehicles and coal mining of Mahanadi coal field and Hakimpada (small industrial area) is the commercial area comprising of small-scale industries and office areas. But in post monsoon A1 (Nalco township) was found to be the most polluted area followed by MCL, coal mining area, TTPS township near Talcher Thermal power plant area and Hakimpada. Two-way ANOVA among compounds and sites during all the seasons showed significant difference both with respect to compounds and sites $(p<0.05)$. Two-way ANOVA among compounds and seasons at Hakimpada, Angul showed significant difference both with respect to compounds and seasons $(p<0.05)$.

At two different sampling sites in Jharsuguda, $\sum_{16} \mathrm{PAHs}$ in $\mathrm{PM}_{10}$ during pre-monsoonal season followed the trend Cox colony (B1) > TRL Colony (B2). Higher concentration of PAHs in Cox colony may be due to vehicular emission from the nearby Highways and emissions from the surrounding industrial region. In monsoon the trend was same i.e., Cox colony (B1) > TRL Colony (B2), may be due to vehicular emission and industrial emissions and during post-monsoon the trend was like TRL Colony (B2) > Cox Colony (B1) may be due to mining activities in winter season by the local mines at close proximity of the study area.

Two way ANOVA among sixteen PAH compounds across all the seasons at Cox colony showed significant difference with respect to compounds $(p<0.05)$ and with respect to seasons $(p>0.05)$. Twoway ANOVA among compounds and across all the seasons at Belpahar showed significant difference with respect to compounds $(p<0.05$,$) and significant difference with respect to seasons (p<0.05)$. Higher concentration was observed during post-monsoon than the pre-monsoon and monsoonal seasons and might be possibly related to the lower temperature, weaker radiation strength and more emission sources (Karar and Gupta, 2006; Valavanidis et al., 2006).

\subsection{Risk assessment}

\subsubsection{TEQs}

Toxic equivalency factors (TEFs) of the individual PAHs have been popularly used to calculate their carcinogenic potential or Benzo(a) pyrene equivalence (BEQ). Comparing the $\sum_{7 \mathrm{carc}} \mathrm{PAHs}$ weight and TEFs, low and higher molecular weight PAHs (BaP, DBa, BaA, BbF, BkF, Ind, Chry and Ant) were the main carcinogenic components of the 16 priority PAHs. The concentration of those components were quite low and their ratios were $0-30 \%$, suggesting the relatively lower human exposure health risk in Angul when comparing with other cities like $69.4 \%$ of San Paulo city (Bourotte et al., 2005), $51.0 \%$ at Las Condes during spring, $54.6 \%$ at Providencia and $56.3 \%$ at Las Condes (del Rosario Sienra et al., 2005).

The potential toxicity of the contaminated air samples was evaluated using the toxic BaP equivalent quotient (TEQ) for seven carcinogenic PAHs. Viz., BaP, BaA, Chysene, BbF, BkF, DBA and InP. Range of TEQs for total PAHs and carcinogenic PAHs in Jharsuguda (Table S14) and Angul (Table S15) for different seasons. Figure 4 shows distribution of total PAHs and carcinogenic PAHs for different seasons.

\subsubsection{Inhalation Risk}


The estimated LADD values of carcinogenic PAHs in PM2.5 and PM 10 for different age groups are presented in the Fig. 5. It can be observed from the figure that during the post monsoon season ILCR was higher in both PM 2.5 and PM 10 (Fig. 5) across all age groups. Across different seasons and age groups, ILCR values for daily inhalation and ingestion exposure to PAHs were higher than the values for daily exposure through dermal contact. This observation was in line with earlier study in South Africa (Morakinyo et al., 2019a). The risk was highest in children in the age group of 2-4 years. Due to the higher concentration of $\mathrm{PM}_{10}$, the ILCR were higher compared with $\mathrm{PM}_{2.5}$. In our study ILCR ranged between $10^{-5}$ and $10^{-3}$ representing potential cancer risk to significant cancer risk (Wang et al., 2011)

\section{Conclusion}

In this study, PAHs concentration at two industrial sites of Odisha were measured in three seasons viz., pre-monsoon, monsoon and post-monsoonal seasons during the year 2017-18. Highest mean concentration of total and carcinogenic PAH was observed in winter season at Angul and Jharsuguda in Odisha. Five ring structured PAH percentage was dominant in all the seasons and in all the locations. Mean concentration of $\sum_{16} \mathrm{PAHs}$ in Jharsuguda was higher than Angul. The qualitative source apportionment presented here indicates that, PC1 represented $52 \%$ of the total variance and was strongly weighted with LMW-PAHs, such as NaP, Ace and Acy and HMW-PAHs viz. BaA, Chry, BkF, DBA and BgP. This component represents PAH source from vehicular emission, coal and gasoline emission. PC 2 represented $17 \%$ variance and was mainly loaded with Flu, Ant, Phe, BbF and BaP. HMW PAHs like four to five rings presumably resulted from the emission of light vehicles and Fluoranthene is also an indicator of heavy-duty diesel combustion. So, this component represents PAH source from heavy duty diesel combustion, coal combustion and biomass burning. The potential toxicity of the contaminated air sample was evaluated using the toxic BaP equivalent quotient (TEQ) was higher for Jharsuguda over Angul. During the post monsoon season ILCR was high in both $\mathrm{PM}_{2.5}$ and $\mathrm{PM}_{10}$ across all age groups.

The risk was highest in children in the age group of 2-4 years. In our study ILCR for both $\mathrm{PM}_{2.5}$ and $\mathrm{PM}_{10}$ ranged between $10^{-5}$ and $10^{-3}$ representing potential cancer risk to significant cancer risk.

\section{Declarations}

\section{Acknowledgement}

We are Thankful to Dr B.N. Bhol, Ex-Chief Scientist, Odisha Pollution Control Board, Bhubaneswar and Head, P.G. Department of Environmental Sciences, Sambalpur University, Odisha for their continuous support during the study period. Thanks to JSAs and Field Assistants of OSPCB who helped during Air Sampling in Angul and Jharsuguda. Grateful to Scientific Research Laboratory, Kolkata for immense support.

\section{Ethics approval and consent to participate}

Not Applicable 


\section{Consent for publication}

Not Applicable

\section{Availability of data and materials}

The datasets used and/or analysed during the current study are available from the corresponding author on reasonable request.

\section{Competing interests}

The authors declare that they have no competing interests

\section{Funding}

Not Applicable

\section{Author's contribution}

Susmita Ekka: Sampling, analysis, data compilation and manuscript writing

Sanjat Kumar Sahu: Data interpretation, graphics and manuscript writing, overall planning and guidance

Sanjeev Dwivedi: HYSPILT Modelling

Sanjenbam Nirmala Khuman: Data interpretation and editing

Shirsendu Das: Experimental analysis and editing

Paromita Chakraborty: Data and manuscript review and editing, overall planning and guidance

\section{References}

1. Agarwal, T., Khillare, P.S., Shridhar, V., Ray, S., 2009. Pattern, sources and toxic potential of PAHs in the agricultural soils of Delhi, India. Journal of Hazardous Materials 163, 1033-1039.

2. Airveda, 2017. What Is PM2.5 and Why Is It Important? available at https://www.airveda.com/blog/what-is-pm2-5-and-why-is-it-important.

3. Akyüz, M., Çabuk, H., 2009. Meteorological variations of PM2. 5/PM10 concentrations and particleassociated polycyclic aromatic hydrocarbons in the atmospheric environment of Zonguldak, Turkey. Journal of Hazardous Materials 170, 13-21.

4. Alves, C.A., Vicente, A.M., Custódio, D., Cerqueira, M., Nunes, T., Pio, C., Lucarelli, F., Calzolai, G., Nava, S., Diapouli, E., 2017. Polycyclic aromatic hydrocarbons and their derivatives (nitro-PAHs, oxygenated PAHs, and azaarenes) in PM2. 5 from Southern European cities. Science of the total environment 595, 494-504. 
5. Bandowe, B.A.M., Meusel, H., Huang, R.-j., Ho, K., Cao, J., Hoffmann, T., Wilcke, W., 2014. PM2. 5bound oxygenated PAHs, nitro-PAHs and parent-PAHs from the atmosphere of a Chinese megacity: seasonal variation, sources and cancer risk assessment. Science of the total environment 473, 77-87.

6. Barrado, A.I., García, S., Castrillejo, Y., Barrado, E., 2013. Exploratory data analysis of PAH, nitro-PAH and hydroxy-PAH concentrations in atmospheric PM10-bound aerosol particles. Correlations with physical and chemical factors. Atmospheric Environment 67, 385-393.

7. Belis, C.A., Cancelinha, J., Duane, M., Forcina, V., Pedroni, V., Passarella, R., Tanet, G., Douglas, K., Piazzalunga, A., Bolzacchini, E., Sangiorgi, G., Perrone, M.G., Ferrero, L., Fermo, P., Larsen, B.R., 2011. Sources for PM air pollution in the Po Plain, Italy: I. Critical comparison of methods for estimating biomass burning contributions to benzo(a)pyrene. Atmospheric Environment 45, 7266-7275.

8. Bourotte, C., Forti, M.-C., Taniguchi, S., Bícego, M.C., Lotufo, P.A., 2005. A wintertime study of PAHs in fine and coarse aerosols in São Paulo city, Brazil. Atmospheric Environment 39, 3799-3811.

9. Caricchia, A.M., Chiavarini, S., Pezza, M., 1999. Polycyclic aromatic hydrocarbons in the urban atmospheric particulate matter in the city of Naples (Italy). Atmospheric Environment 33, 3731-3738.

10. Carreras, H.A., Calderón-Segura, M.E., Gómez-Arroyo, S., Murillo-Tovar, M.A., Amador-Muñoz, O., 2013. Composition and mutagenicity of PAHs associated with urban airborne particles in Córdoba, Argentina. Environmental Pollution 178, 403-410.

11. Chen, C.-W., Chen, C.-F., 2011. Distribution, origin, and potential toxicological significance of polycyclic aromatic hydrocarbons (PAHs) in sediments of Kaohsiung Harbor, Taiwan. Marine pollution bulletin $63,417-423$.

12. Chen, S.-J., Su, H.-B., Chang, J.-E., Lee, W.-J., Huang, K.-L., Hsieh, L.-T., Huang, Y.-C., Lin, W.-Y., Lin, C.-C., 2007. Emissions of polycyclic aromatic hydrocarbons (PAHs) from the pyrolysis of scrap tires. Atmospheric Environment 41, 1209-1220.

13. Cheng, H., Deng, Z., Chakraborty, P., Liu, D., Zhang, R., Xu, Y., Luo, C., Zhang, G., Li, J., 2013. A comparison study of atmospheric polycyclic aromatic hydrocarbons in three Indian cities using PUF disk passive air samplers. Atmospheric Environment 73, 16-21.

14. Christensen, E.R., Bzdusek, P.A., 2005. PAHs in sediments of the Black River and the Ashtabula River, Ohio: source apportionment by factor analysis. Water Research 39, 511-524.

15. Cincinelli, A., Del Bubba, M., Martellini, T., Gambaro, A., Lepri, L., 2007. Gas-particle concentration and distribution of $n$-alkanes and polycyclic aromatic hydrocarbons in the atmosphere of Prato (Italy). Chemosphere 68, 472-478.

16. del Rosario Sienra, M., Rosazza, N.G., Préndez, M., 2005. Polycyclic aromatic hydrocarbons and their molecular diagnostic ratios in urban atmospheric respirable particulate matter. Atmospheric Research 75, 267-281.

17. Draxler, R.R., Stunder, B., Rolph, G., Stein, A., Taylor, A., 1999. HYSPLIT $\underline{4}$ Users's Guide. US Department of Commerce, National Oceanic and Atmospheric Administration ....

18. Eeftens, M., Tsai, M.-Y., Ampe, C., Anwander, B., Beelen, R., Bellander, T., Cesaroni, G., Cirach, M., Cyrys, J., de Hoogh, K., 2012. Spatial variation of PM2. 5, PM10, PM2. 5 absorbance and PMcoarse 
concentrations between and within 20 European study areas and the relationship with NO2-results of the ESCAPE project. Atmospheric Environment 62, 303-317.

19. EPA, U., 1993. Provisional guidance for quantitative risk assessment of polycyclic aromatic hydrocarbons. Development.

20. Feng, J., Chan, C.K., Fang, M., Hu, M., He, L., Tang, X., 2005. Impact of meteorology and energy structure on solvent extractable organic compounds of PM2. 5 in Beijing, China. Chemosphere 61, 623-632.

21. Gogou, A., Stratigakis, N., Kanakidou, M., Stephanou, E.G., 1996. Organic aerosols in Eastern Mediterranean: components source reconciliation by using molecular markers and atmospheric back trajectories. Organic Geochemistry 25, 79-96.

22. Hegarty, J., Draxler, R.R., Stein, A.F., Brioude, J., Mountain, M., Eluszkiewicz, J., Nehrkorn, T., Ngan, F., Andrews, A., 2013. Evaluation of Lagrangian particle dispersion models with measurements from controlled tracer releases. Journal of Applied Meteorology and Climatology 52, 2623-2637.

23. Hong, H., Yin, H., Wang, X., Ye, C., 2007. Seasonal variation of PM10-bound PAHs in the atmosphere of Xiamen, China. Atmospheric Research 85, 429-441.

24. Karar, K., Gupta, A., 2006. Seasonal variations and chemical characterization of ambient PM10 at residential and industrial sites of an urban region of Kolkata (Calcutta), India. Atmospheric Research 81, 36-53.

25. Kaur, S., Senthilkumar, K., Verma, V., Kumar, B., Kumar, S., Katnoria, J.K., Sharma, C., 2013. Preliminary analysis of polycyclic aromatic hydrocarbons in air particles (PM10) in Amritsar, India: sources, apportionment, and possible risk implications to humans. Archives of environmental contamination and toxicology 65, 382-395.

26. Kavouras, I.G., Lawrence, J., Koutrakis, P., Stephanou, E.G., Oyola, P., 1999. Measurement of particulate aliphatic and polynuclear aromatic hydrocarbons in Santiago de Chile: source reconciliation and evaluation of sampling artifacts. Atmospheric Environment 33, 4977-4986.

27. Kulkarni, K., Sahu, S., Vaikunta, R., Pandit, G., Lakshmana, D., 2014. Characterization and source identification of atmospheric polycyclic aromatic hydrocarbons in Visakhapatnam, India. Int. Res. J. Environ. Sci 3, 57-64.

28. Li, P., Xue, R., Wang, Y., Zhang, R., Zhang, G., 2015. Influence of anthropogenic activities on PAHs in sediments in a significant gulf of low-latitude developing regions, the Beibu Gulf, South China Sea: distribution, sources, inventory and probability risk. Marine pollution bulletin 90, 218-226.

29. Lodovici, M., Venturini, M., Marini, E., Grechi, D., Dolara, P., 2003. Polycyclic aromatic hydrocarbons air levels in Florence, Italy, and their correlation with other air pollutants. Chemosphere 50, 377-382.

30. Marr, L.C., Kirchstetter, T.W., Harley, R.A., Miguel, A.H., Hering, S.V., Hammond, S.K., 1999. Characterization of Polycyclic Aromatic Hydrocarbons in Motor Vehicle Fuels and Exhaust Emissions. Environmental Science \& Technology 33, 3091-3099.

31. Masih, A., Saini, R., Singhvi, R., Taneja, A., 2010. Concentrations, sources, and exposure profiles of polycyclic aromatic hydrocarbons (PAHs) in particulate matter (PM 10) in the north central part of 
India. Environmental monitoring and assessment 163, 421-431.

32. Maurer, C., Baré, J., Kusmierczyk-Michulec, J., Crawford, A., Eslinger, P.W., Seibert, P., Orr, B., Philipp, A., Ross, O., Generoso, S., 2018. International challenge to model the long-range transport of radioxenon released from medical isotope production to six Comprehensive Nuclear-Test-Ban Treaty monitoring stations. Journal of environmental radioactivity 192, 667-686.

33. McGrath, T.E., Wooten, J.B., Geoffrey Chan, W., Hajaligol, M.R., 2007. Formation of polycyclic aromatic hydrocarbons from tobacco: The link between low temperature residual solid (char) and PAH formation. Food and Chemical Toxicology 45, 1039-1050.

34. Mohanraj, R., Solaraj, G., Dhanakumar, S., 2011. PM 2.5 and PAH concentrations in urban atmosphere of Tiruchirappalli, India. Bulletin of Environmental Contamination and Toxicology 87, 330-335.

35. Moon, H.-B., Kannan, K., Lee, S.-J., Ok, G., 2006. Atmospheric deposition of polycyclic aromatic hydrocarbons in an urban and a suburban area of Korea from 2002 to 2004. Archives of Environmental Contamination and Toxicology 51, 494-502.

36. Morakinyo, O.M., Mukhola, M.S., Mokgobu, M.I., 2019a. Concentration levels and carcinogenic and mutagenic risks of PM 2.5-bound polycyclic aromatic hydrocarbons in an urban-industrial area in South Africa. Environmental Geochemistry and Health, 1-16.

37. Morakinyo, O.M., Mukhola, M.S., Mokgobu, M.I., 2019b. Concentration levels and carcinogenic and mutagenic risks of PM(2.5)-bound polycyclic aromatic hydrocarbons in an urban-industrial area in South Africa. Environ Geochem Health.

38. Nasher, E., Heng, L.Y., Zakaria, Z., Surif, S., 2013. Assessing the ecological risk of polycyclic aromatic hydrocarbons in sediments at Langkawi Island, Malaysia. The Scientific World Journal 2013.

39. Odabasi, M., Vardar, N., Sofuoglu, A., Tasdemir, Y., Holsen, T.M., 1999. Polycyclic aromatic hydrocarbons (PAHs) in Chicago air. Science of the Total Environment 227, 57-67.

40. Omar, N.Y.M., Abas, M.R.B., Ketuly, K.A., Tahir, N.M., 2002. Concentrations of PAHs in atmospheric particles (PM-10) and roadside soil particles collected in Kuala Lumpur, Malaysia. Atmospheric Environment 36, 247-254.

41. Peters, C.A., Knightes, C.D., Brown, D.G., 1999. Long-term composition dynamics of PAH-containing NAPLs and implications for risk assessment. Environmental Science \& Technology 33, 4499-4507.

42. Ping, L.F., Luo, Y.M., Zhang, H.B., Li, Q.B., Wu, L.H., 2007. Distribution of polycyclic aromatic hydrocarbons in thirty typical soil profiles in the Yangtze River Delta region, east China. Environmental Pollution 147, 358-365.

43. Pio, C., Alves, C., Duarte, A., 2001. Organic components of aerosols in a forested area of central Greece. Atmospheric Environment 35, 389-401.

44. Possanzini, M., Di Palo, V., Gigliucci, P., Scianò, M.C.T., Cecinato, A., 2004. Determination of phasedistributed PAH in Rome ambient air by denuder/GC-MS method. Atmospheric Environment 38, 17271734. 
45. Ravindra, K., Wauters, E., Van Grieken, R., 2008. Variation in particulate PAHs levels and their relation with the transboundary movement of the air masses. Science of the Total Environment 396, 100-110.

46. Rogge, W.F., Hildemann, L.M., Mazurek, M.A., Cass, G.R., Simoneit, B.R.T., 1993. Sources of fine organic aerosol. 2. Noncatalyst and catalyst-equipped automobiles and heavy-duty diesel trucks. Environmental Science \& Technology 27, 636-651.

47. Sarkar, S., Khillare, P., 2013. Profile of PAHs in the inhalable particulate fraction: source apportionment and associated health risks in a tropical megacity. Environmental monitoring and assessment 185, 1199-1213.

48. Singh, D.K., Sharma, S., Habib, G., Gupta, T., 2015. Speciation of atmospheric polycyclic aromatic hydrocarbons (PAHs) present during fog time collected submicron particles. Environmental Science and Pollution Research 22, 12458-12468.

49. Stein, A., Draxler, R.R., Rolph, G.D., Stunder, B.J., Cohen, M., Ngan, F., 2015. NOAA's HYSPLIT atmospheric transport and dispersion modeling system. Bulletin of the American Meteorological Society 96, 2059-2077.

50. Tavakoly Sany, S., Hashim, R., Salleh, A., Rezayi, M., Mehdinia, A., Safari, O., 2014. Polycyclic aromatic hydrocarbons in coastal sediment of Klang Strait, Malaysia: distribution pattern, risk assessment and sources. PloS one 9, e94907.

51. Valavanidis, A., Fiotakis, K., Vlahogianni, T., Bakeas, E.B., Triantafillaki, S., Paraskevopoulou, V., Dassenakis, M., 2006. Characterization of atmospheric particulates, particle-bound transition metals and polycyclic aromatic hydrocarbons of urban air in the centre of Athens (Greece). Chemosphere 65, 760-768.

52. Vasconcellos, P.C., Zacarias, D., Pires, M.A.F., Pool, C.S., Carvalho, L.R.F., 2003. Measurements of polycyclic aromatic hydrocarbons in airborne particles from the metropolitan area of São Paulo City, Brazil. Atmospheric Environment 37, 3009-3018.

53. Wang, G., Kawamura, K., Zhao, X., Li, Q., Dai, Z., Niu, H., 2007. Identification, abundance and seasonal variation of anthropogenic organic aerosols from a mega-city in China. Atmospheric Environment 41, 407-416.

54. Wang, J., Geng, N.B., Xu, Y.F., Zhang, W.D., Tang, X.Y., Zhang, R.Q., 2014. PAHs in PM 2.5 in Zhengzhou: concentration, carcinogenic risk analysis, and source apportionment. Environmental monitoring and assessment 186, 7461-7473.

55. Wang, W., Huang, M.j., Kang, Y., Wang, H.-s., Leung, A.O., Cheung, K.C., Wong, M.H., 2011. Polycyclic aromatic hydrocarbons (PAHs) in urban surface dust of Guangzhou, China: Status, sources and human health risk assessment. Science of the total environment 409, 4519-4527.

56. Wang, X., Cheng, H., Xu, X., Zhuang, G., Zhao, C., 2008. A wintertime study of polycyclic aromatic hydrocarbons in PM2. 5 and PM2. 5-10 in Beijing: assessment of energy structure conversion. Journal of Hazardous Materials 157, 47-56.

57. Wang, X.Y., Li, Q.B., Luo, Y.M., Ding, Q., Xi, L.M., Ma, J.M., Li, Y., Liu, Y.P., Cheng, C.L., 2010. Characteristics and sources of atmospheric polycyclic aromatic hydrocarbons (PAHs) in Shanghai, 
China. Environmental Monitoring and Assessment 165, 295-305.

58. Yunker, M.B., Macdonald, R.W., Vingarzan, R., Mitchell, R.H., Goyette, D., Sylvestre, S., 2002. PAHs in the Fraser River basin: a critical appraisal of PAH ratios as indicators of PAH source and composition. Organic Geochemistry 33, 489-515.

59. Zhang, H.B., Luo, Y.M., Wong, M.H., Zhao, Q.G., Zhang, G.L., 2006. Distributions and Concentrations of PAHs in Hong Kong Soils. Environmental Pollution 141, 107-114.

\section{Figures}

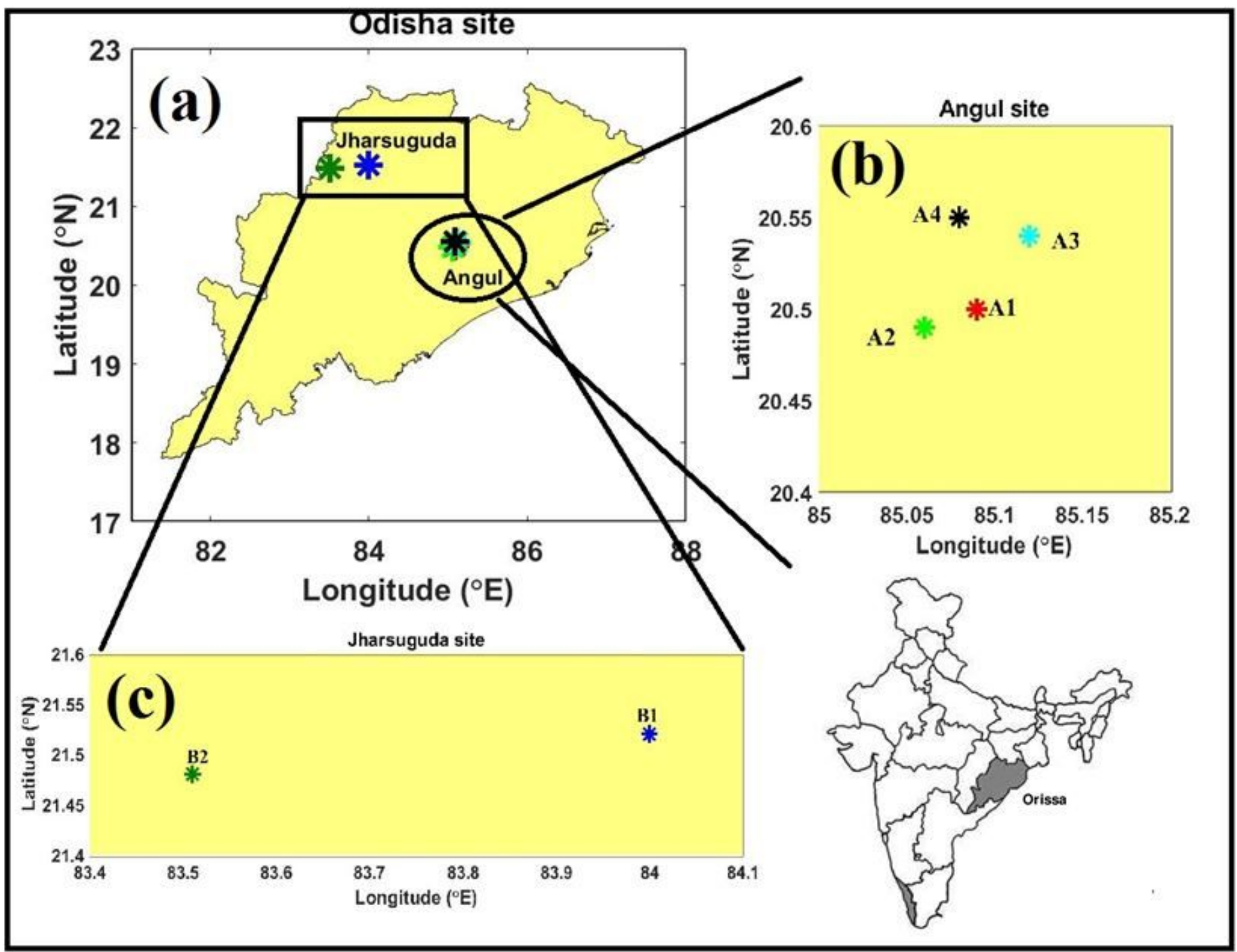

Figure 1

Sampling locations in Orissa Note: The designations employed and the presentation of the material on this map do not imply the expression of any opinion whatsoever on the part of Research Square concerning the legal status of any country, territory, city or area or of its authorities, or concerning the delimitation of its frontiers or boundaries. This map has been provided by the authors. 

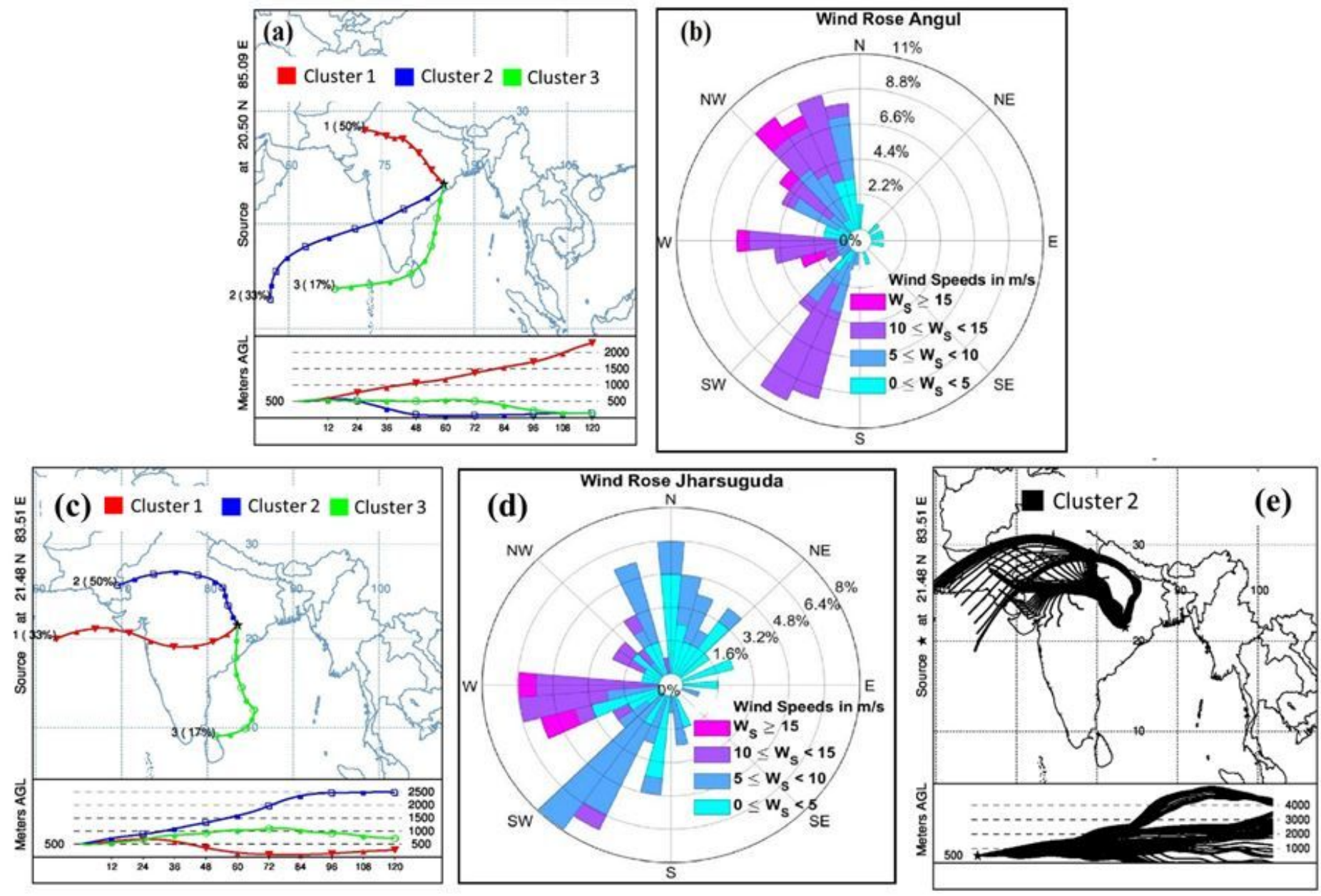

\section{Figure 2}

(a) Cluster means at 500 m Above Ground Level (AGL) from 144 five days back trajectories (6 Days x 24 hours $=144$ ) using HYSPLIT model over the Angul site $(85.09 \mathrm{oE}$ and $20.50 \mathrm{oN})$, (b) Wind Rose using the Radiosonde data (below $4 \mathrm{~km}$ ) from University of Wyoming upper air data over Bhubaneswar (85.83oE and $20.25 \mathrm{oN}$ ) for the corresponding days and frequency label defines frequency in each direction; (c) Cluster means at $500 \mathrm{~m}$ AGL from 144 five days back trajectories ( 6 Days $\times 24$ hours $=144)$ using HYSPLIT model over the Jharsuguda site (83.51oE and 20.48oN), (d) Wind Rose using the Radiosonde data (below $4 \mathrm{~km}$ ) from university of Wyoming upper air data over Bhubaneswar (85.83oE and 20.25oN) for the corresponding days and frequency label defines frequency in each direction;(e) Cluster 2 almost $50 \%$ over Jharsuguda showing 72 trajectories crossing over Indo - Gangatic Plain. Note: The designations employed and the presentation of the material on this map do not imply the expression of any opinion whatsoever on the part of Research Square concerning the legal status of any country, territory, city or area or of its authorities, or concerning the delimitation of its frontiers or boundaries. This map has been provided by the authors. 

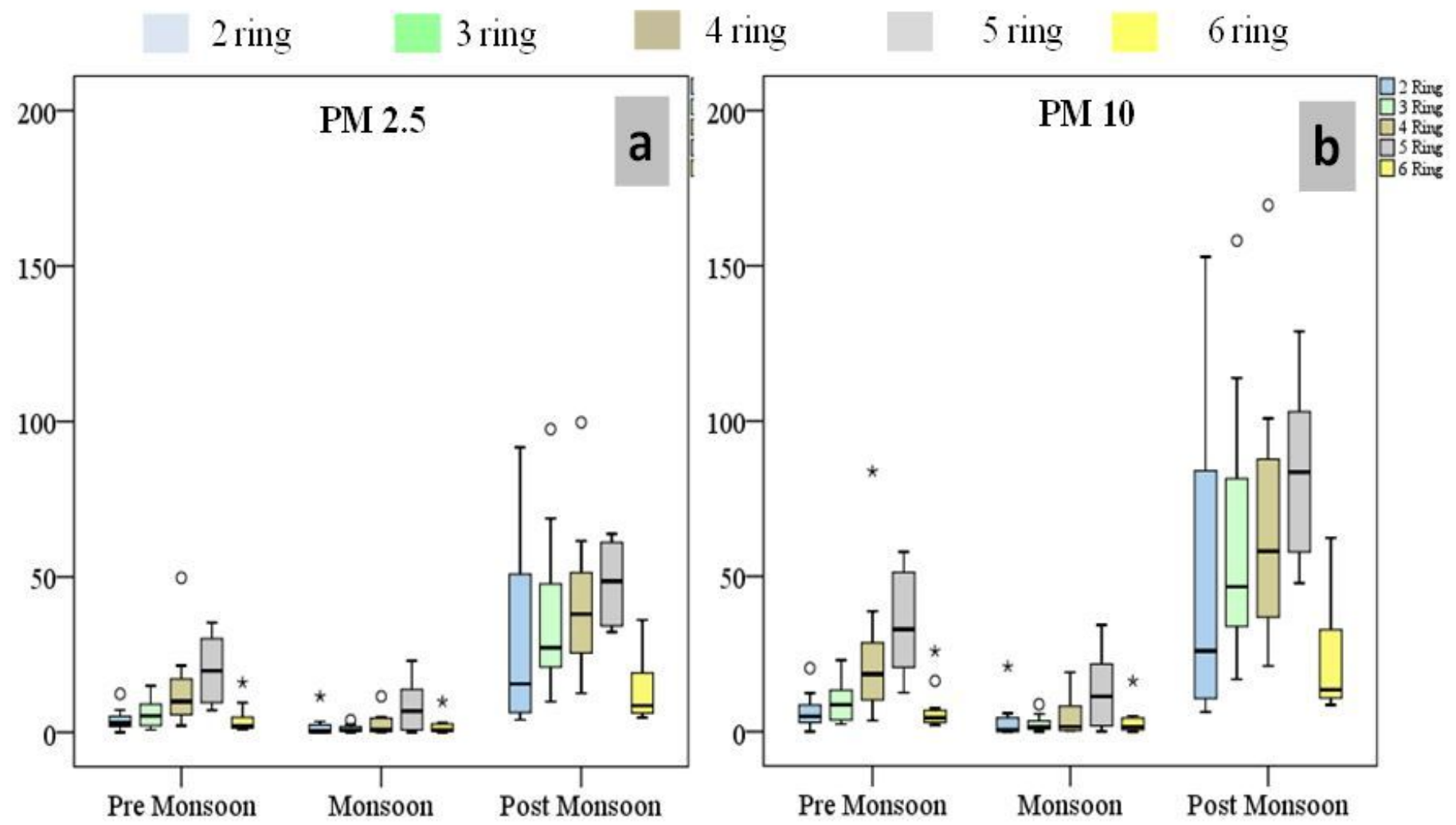

Figure 3

Box whisker plots showing the ring wise distribution of PAHs during different seasons in (a) PM 2.5 and (b) PM 10 at Angul and Jharsuguda in Orissa
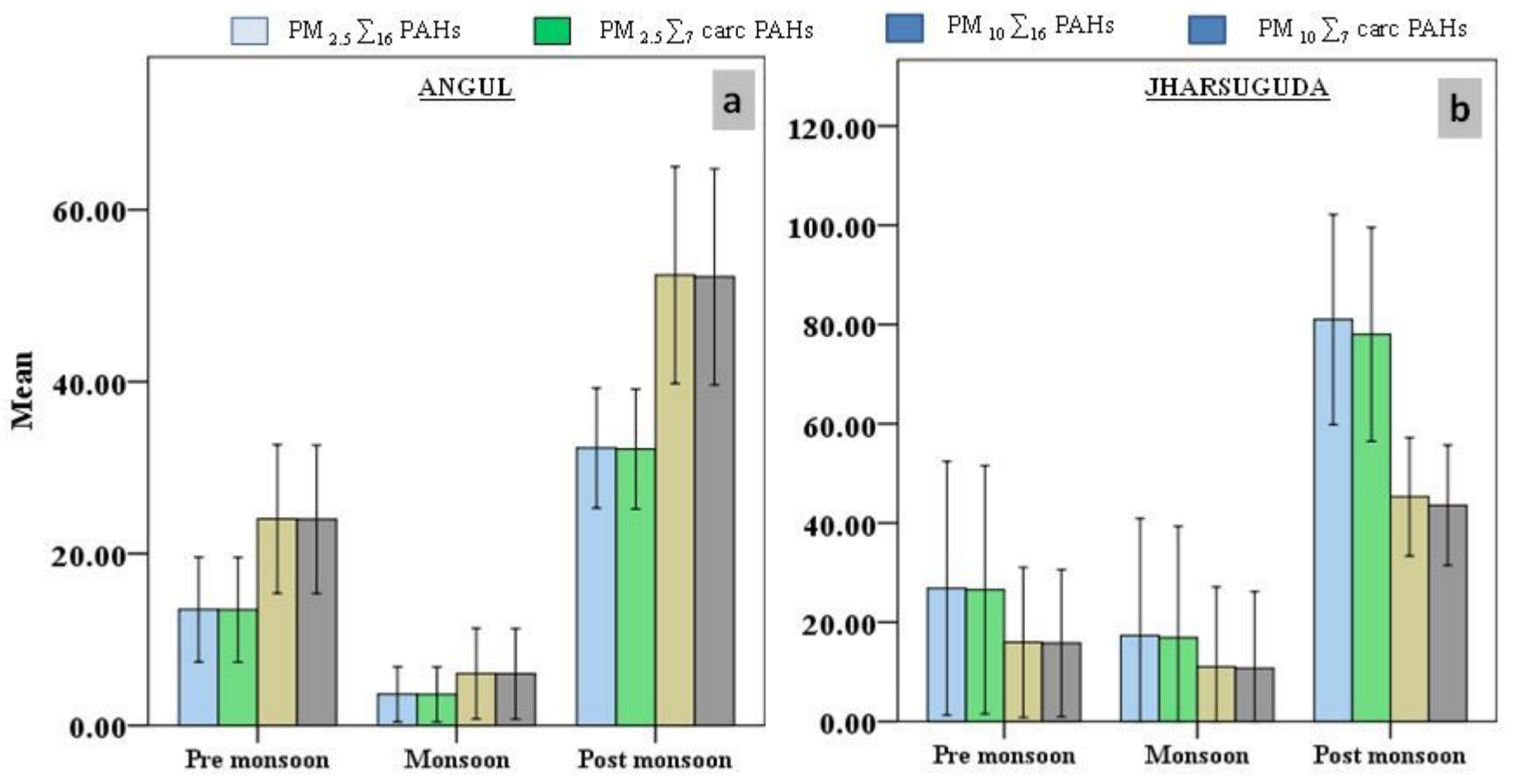
Figure 4

Error plots showing distribution of total PAHs and carcinogenic PAHs in PM 2.5 and PM 10 at (a) Angul and (b) Jharsuguda in Orissa

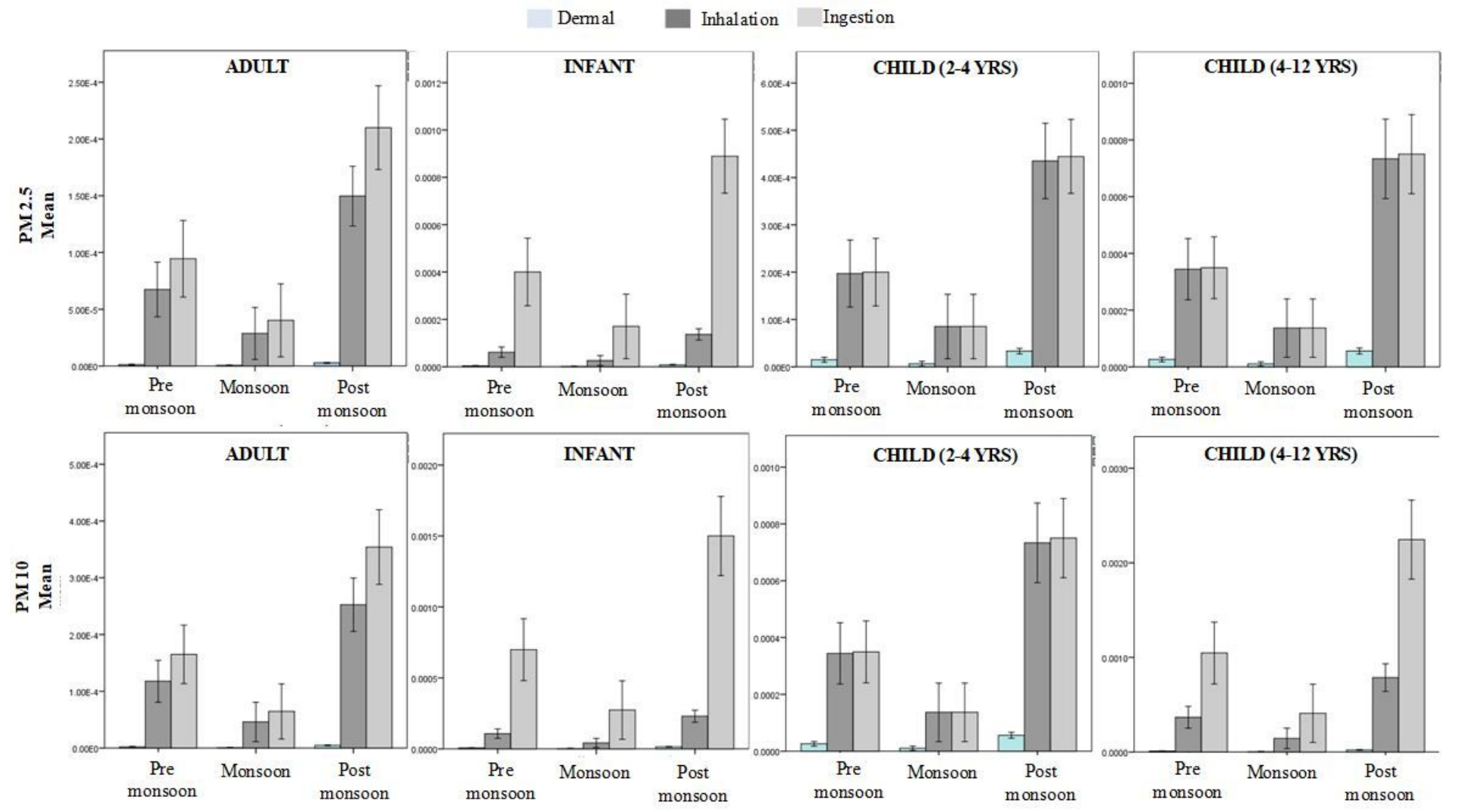

Figure 5

ILCR for carcinogenic PAHs

\section{Supplementary Files}

This is a list of supplementary files associated with this preprint. Click to download.

- Supportinglnformation25012021PC.doc 